https://jurnal.ugm.ac.id/rubikon

\title{
BOAZ HAGIN'S PHILOSOPHY OF DEATH AS REFLECTED IN THE HUNGER GAMES TRILOGY FILMS
}

\author{
Hidayatul Nurjanah \\ IAIN Surakarta \\ e-mail: hidayatul.nurjanah@iain-surakarta.ac.id
}

\begin{abstract}
The Hunger Games is one of Hollywood films that contains deaths and deadly scenes throughout its trilogy. There are plenteous meanings of deaths that can be analyzed from the films, which will develop new meanings and definitions of deaths as an interesting topic to discuss. The researcher employed Boaz Hagin's framework of death because Hagin provides a framework about deaths and how deaths can be meaningful. In his book, he writes a broader range of philosophical description about deaths in Classical Hollywood Cinema which explores the morality and ethical values of mainstream films that portrays death as a meaningful part of life. The research problem is what is the meaning of deaths found in Hunger Games using Hagin's framework of deaths. This research was conducted using a descriptive qualitative approach aiming at describing the phenomenon and characteristics. The data collected qualitatively by examining them throughout to get relevant issues and ideas and classify them. The findings show that death can bring meanings to characters in the films, such as a death in line where death means as a savior for their beloved ones, death as politic seen from the characters' past life that brings hope for the future, death as the Access, Authority, and Test, can be seen from how the characters use their talent to survive.
\end{abstract}

Article information

Keywords: Boaz Hagin; death; death films; philosophy of death; The Hunger Games trilogy films

DOI $\quad$ : https://doi.org/10.22146/rubikon.v8i1.65482

Available at https://jurnal.ugm.ac.id/rubikon/article/view/65482

This work is licensed under a Creative Commons Attribution-ShareAlike 4.0 International License 


\section{INTRODUCTION}

Death is mysterious, and that is why death is interesting to discuss. Death itself is something inevitable that happens to every living creature, including human beings. Death itself, unlike many philosophical and religious ideas, affects each other as the encounter of the death of the loved ones, the famous ones, or those the hated ones. In broadest terms, a person is likely to first encounter death as the death of others, for example, the death of a neighbor, which bring little impacts, or the death of family or idol, which creates serious impacts and a high degree of emotion over the death (Davis, 2005, p. 15-16).

The attitudes towards death have also been discussed by many researchers for years. As Kubler-Ross mention in her book, people's attitude toward death is influenced by who died, the causes of the death, and how he dying people faced their death (2009: 25). According to Adkins, there are many phenomena that drive death, such as diseases, accidents, natural disasters, wars, medicines, technologies, and even suicides. The terrifying death, such as the loss of a beloved person because of wars or murders, leads to mourning and melancholic situation that cannot be accepted by the lost person or family (2007, p. 1-3). Whatever the cause, every living creature will face death. Some may live longer than others, and some may live shorter than others. All living creature will maintain their lives, try to elude themselves from death, or keep at the distance from death even though it is an assured thing that death is without doubt and unstoppable.

Furthermore, according to sociologist Zygmunt Bauman, death is seen as the most trustworthy experience in human life; death remains inexplicable and unknown. People, therefore, need to encounter the death experience in other ways, such as by watching and following the death of others, as well as with the help of fiction, imagining how it will feel (Bauman, 1992). The German philosopher and literary critic Walter Benjamin was another scholar who claimed that what we seek in fiction is the knowledge of death that is denied to us in real life. Literature can provide us with ways of approaching death and imagining it from different perspectives. Some literary genres (elegies, lamentations) are intentionally written as reactions to the loss of a loved object or a person, and literature can act as consolation to those who are suffering (Hakola and Sari Kivistö, 2014, p. 10).

Interestingly, the attitudes in giving meaning towards death have been changing from time to time. As Aries (1976) mentioned in his book that people have dynamic changing in interpreting and giving meaning to death. Started from the oldest and the longest, people were aware of death; everybody shall all die. Death was desirable, people dead in bed and surrounded by the family, and they brought children to the death chamber to say farewell to the dying person. In the twelfth century, people gave the meaning of death in one's death; death had become a more important event; more thought was given to it. In the 1800 s, a new definition was given to death in western societies; death was no longer desirable, everybody was less concerned about their death or even other people's death. In the nineteenth century, death was accepted in greater difficulty than in the past; it was also known as the mourning era (1976, p. 55-58). 
One of the American authors who write a story that contains numerous meanings of death and also the assorted drives to death is Suzanne Collins. She is well-known for her trilogy novel entitled The Hunger Games, The Hunger Games: Catching Fire, The Hunger Games: Mockingjay. These novels have been adapted into films which reached huge enthusiasm from many audiences all over the world. The first sequel was the third-largest of any movie in North America after Avatar, which is in the first place (Whited, 2012, p. 329). In the films, we can analyze more about how death can be meaningful or even meaningless seen from its storylines and scenes.

The story of The Hunger Games trilogy tells about the dystopian nation called Panem, which consists of wealthy people, glamorous capitol, and ruled by an evil regime President Snow who rules for twelve more impoverished districts. He enforces a game as the punishment for all districts for a past rebellion and as a way to quell social disturbance by commanding each district to provide two tributes, one boy and one girl between the ages of 12 and 18 selected by lottery (the reaping) every year as the representation from the districts to compete in the television on blood sport; they must fight to the death in a vast arena, with the sole survivor rewarded with fame and wealth.

In the game, there are many death pictures, starting from the most terrible death until the glorious death. Each of the tributes must survive themselves to stay alive in the game by murdering other tributes until she or he becomes the last person standing in an atomic plane and go back to Capitol. The bloodshed happens every time and everywhere, cheating, disaster, and much violence filling the game. The last sequel still provides much violence with bloodshed everywhere. Basically, the main theme of death in the films is still dominant, and what are the drives toward death are also depicted in the films continuously. The deaths in the film have many meanings that we can analyze. For example, the death itself in the film represents capitalism tendency; superpower rules the subordinate where the president Snow forces each district to send two "tributes" to the game, where specifically, it is just a game for rich people to entertain them by playing death.

Based on the starting point above, here, the writer wants to analyze the death in The Hunger Games trilogy films to find the meaning of death reflected in the films. Here, in keeping away from broad discussion, this research is limited to make more profound research and more comprehensive analysis. Based on the reasons above, the researcher deals with the research question of what is the meaning of death in The Hunger Games trilogy film; The Hunger Games, The Hunger Games: Catching Fire, The Hunger Games: Mockingjay - Part 1 using Boaz Hagin's framework on death in Classical Hollywood Cinema. The objective of the research is to find the meaning of death reflected in The Hunger Games trilogy film. The significance of the research is to give knowledge and information for academic students to find the meaning of death using Hagin's framework of death in Classical Hollywood Cinema.

The descriptive qualitative approach was used in writing and gathering the information and (Creswell, 2009: 186). In collecting the data, three steps were taken; watching the movie several times, then taking notes during the watching and interpreting or analyzing. In the writing process, the library research method was 
used to collect the data and information about the topic of the analysis (Krippendorf, 1981, p. 21).

Using Hagin's framework of death in Classical Hollywood Cinema book, this discussion will analyze the meaning of death started from the death on the line, a rehearsal death, access, authority, and test, the killability test, sublating death, obstacles and goals, desiring death, and retaining the death and how each of the death is explained thought out the deaths in The Hunger Game trilogy films.

Boaz Hagin is a senior lecturer at the Department of Film and Television, Tel Aviv University, and was visiting scholar at NYU. He writes a book entitled Death in Classical Hollywood Cinema (2010). In his book, he writes a broader range of philosophical description about death in Classical Hollywood Cinema which explores the morality and ethical values of mainstream films that portrays death as a meaningful part of life. He provides challenges and constraints for making death meaningful characterized by a causal, linear, individual-driven narrative and excessive melodramatic spectacles (Sterritt, 2011, p. 78-79). In his book, Hagin describes many frameworks of death that can be used to analyze the meaning of death in films. For example, Death on the Line underlines how death can be meaningful in philosophy by making a connection between morality and time.

He provides some films as an example in order to construct the various concepts or ways of thinking about death as meaning in Classical Hollywood Cinema (Amstrong, 2011, p. 126). In Hollywood narrative, which centered on causality, consequence, psychological motivations, and the drive toward overcoming obstacles and achieving goals, Hagin gives an explanation on how death can be meaningfully in functions in relation to events that come before or after it in a personal linear causal storyline.

This research employs Hagin's framework of deaths because Hagin uses films, especially Hollywood films, as examples for his theory. Hagin found death meaning patterns in Hollywood film production which have similar meanings both towards the characters or stories projected in the films. The films can also be animation films and cartoons. Therefore, as one of the popular or mainstream films in Hollywood which projects deaths and deadly scenes throughout the entire story, Hunger Games films, this research applying Hagin's framework of deaths to analyze the meaning of deaths in Hunger Games trilogy films.

\section{DISCUSSION}

The researcher found numerous scenes in The Hunger Games trilogy films that reflect how death can be meaningful using Hagin's framework of death in Classical Hollywood Cinema. He provides some films as an example in order to construct the various concepts or ways of thinking about death as meaning in Classical Hollywood Cinema (Amstrong, 2011, p. 126). In his book, he writes a broader range of philosophical description about death which explores the morality and ethical values of mainstream films that portrays death as a meaningful part of life. He also provides challenges and constraints for making death meaningful characterized by a causal, linear, individualdriven narrative and excessive melodramatic spectacles (Sterritt, 2011, p. 78-79). 


\section{Death on the Line}

In this discussion, the researcher analyzed how death can be meaningful in philosophy by making a connection between mortality and time started from Death on the Line. Here, Death on the Line can be found in The Hunger Games scene where Katniss Everdeen has to deal with the games to protect her district, district twelve, from destruction. The past rebellion by all districts, including Katniss district, caused many dead people to encourage Katniss to win the game and save the district from Panem's punishment instead of saving her own family, Prim and her mother. Here, what Hagin tries to say by coining death on the Line is that the connection between death and time creates new meaning on death which is the eagerness to stay alive and motivate the characters, especially the protagonist ones. As Hagin mentioned in his book that death in line could be meaningful because it functions in relation to events that come before and after it in a personal linear causal storyline (2010, p. 0405).

The morality value here lies in how the death from the past can save the death of the living people in the future. The next scene in The Hunger Games: Catching Fire where a great number of people from all districts gather to unite a rebellion by exploding the main bridge of the Capitol, which contains the main electricity supplies to paralyze the system of Panem can help the rescuer armies entering the main building to evacuate Peeta and other tributes. Here, even though the rebellions died for the explosion, yet their death can open huge change for revolution and freedom for everybody in the districts. The psychological motivation by Katniss in remembering his father's death also leads her to start acting as Mockingjay as the symbol of rebellion to destroy the Capitol and start a new life with the new Panem. Here, Hagin also stated that death needs to be meaningful not only by being a cause and or effect within a linear or individual-driven storyline. It also needs to be justified (p. 06-07).

In the Politic of Death, we can see through the general view of the films how death can be meaningful in relation to the political interest seen from Katniss and all the members of the new district thirteen to start a new revolution by destroying President Snow's reign and creating new Panem. In the Politic of Death, Hagin writes how death can be meaningful in relation to the political interest provided in the films. Death can reveal a hidden truth; for example, the death of one person reveals the truth about the justice that does not appear before it (2010, p. 08). Interestingly, at the end of the trilogy film, there was a scene where Katniss, as the main character who was supposed to kill Snow for his demoniac crimes, actually shot President Alma Coin to death because Katniss found the truth that the new president would bring their life into the worst disaster.

Moreover, the death of numerous people in almost all districts triggers the rebellious capitols to take revenge on the Capitol. Meanwhile, the political interest provided in the film can be seen through the initials of The Hunger Games itself, where the game has a purpose for the enemy, which is the Capitol, to take control of the twelve districts to comply with the Capitol's system. The Hunger Games itself created as punishment for the uprising from the twelve districts in the past, each of the twelve districts must provide one girl and one boy, called tributes, to participate. For several weeks, the competitors must fight to 
the death. The last tribute standing wins. The death from the lost tribute is aimed as the symbol of the Capitol for their power and dominance. This reason behind the game created by the Capitol itself is already a political symbol from the superpower Capitol to all colonialized districts and acts as means of power control. Therefore, deaths, as resulted during this game, can also be categorized as politics of death.

\section{A Rehearsal of Death}

This death is meaningful not by changing what has already happened but by revealing it. Death can be the key to gain knowledge (2010: 12-13). Hagin provides the example where the death of someone can reveal knowledge about medical education, especially surgery. It can help in developing technologies for the sake of humanity. In the film, the characters of Beetee Latier and Wiress have made many attempts to prove their theory that the arena was built by man, not the real world. Even though their hypothesis took many deaths of their friends, they managed to find the technology behind the game arena and together fought with the main character by the end of the story. This proves that death can reveal technology and hidden truth for the sake of humanity.

Another definition of death as the rehearsal of death can be seen when the main characters decided to end their lives than killing each other to decide the winner. The decision by both characters to eat poisonous berries can be symbolized as the way to reach freedom, both died, or the way to trick the Capitol to reveal what stages the characters would face next. In response, rather than being humiliated in front of the districts, the Capitol allows the couple to win together. The other districts watching the Games have now witnessed an act of rebellion, a new hope for freedom and peace. This rehearsal of death, by simply definition, is death that gives freedom from what entangled them in order to be free; in other words, death a pleasure and sincere act of killing themselves.

The rehearsal death also can be seen in the third sequel, The Hunger Games: Mockingjay - Part 1, which depicts Katniss revolution against the Capitol and President Snow. The insurgents by district 13 pointed to Katniss as the symbol of their rebellion. The Hunger Games turns into an act of rebellion where many people died both from the insurgents and the Capitol. Here, there was a scene where Peeta was forced to make an interview aired lively to stop Katniss rebellion. Peeta, with his chance aired on TV, foisted information pointed to Katniss that the Capitol has the plan to destroy district 13 and have known their coordinate. By airing this information, Peeta was ready for his death and punishment from the Capitol. But, for this braveness, all the people in district 13 were saved and could escape from the massive and explosive attack.

\section{Access, Authority, and Test}

Hagin mentioned that death could bring about a shift from ignorance to knowledge. It can be a discovery of new information or the disclosure of a secret (2010, p. 13). How the death can be meaningful in the shifting from ignorance to knowledge and also as a test can be found in The Hunger Games scene where Peeta was hunting meals alone for his living and Katniss. $\mathrm{He}$ found berries called Nightlock, and he was not aware of that poisoned berries which can drive anyone to death in a minute from eating it until Katniss 
came shouting at him to do not eat the berries and show the dead body of the girl from district nine. Katniss showed him the girl's mouth, surrounded by berries, and Peeta later knows that his life was just saved by Katniss' outstanding knowledge. The death of the other tribute caused by poisoned berries gained Peeta's knowledge in differentiating the food which can and cannot be consumed. In this case, Peeta was saved from death by Katniss for her knowledge. In some cases, death can simply be a fatal result of acting in a way that enables one to gain knowledge.

As the result of a test, death is meant to measure the correct or incorrect hypothesis. The researcher found the scene in The Hunger Game where Katniss and Peeta were informed by their mentor, Haymitch, to do not to set the fire in the arena. Haymitch did not explain why setting a fire is not allowed during the game in any situation until Katniss found herself seeing fire smoke from the top of the tree and heard a girl's screaming; presumably, she was killed by other tributes. Here, the death of the lost tribute can measure the hypothesis of whether Haymitch's suggestion was correct or not if setting a fire can cause deadly consequences for the tributes. Katniss learned the result of the test and the death of the lost tribute could save her life.

Hagin also mentioned that some forms of knowledge could be discovered through practices, even, or especially, if that might have deadly consequences. This can be seen almost through all the entire actions while playing the game in the arena. It can be said that only the one(s) who have knowledge or at least have the intention to learn is the one(s) who will stay alive and escape from death.

\section{The Killability Test}

Hagin portrays how death can bring enlightenment; from ignorance to knowledge. Death can also be the fatal result of acting in a way that enables people to gain knowledge. Death is used as a result of a test (2010, p. 1213). The scene where the tributes arrived for the first time in the arena in The Hunger Games shows the meaning of death as the killability test. There were thirteen tributes died for their killability because they cannot defend themselves from other tributes' attack; the lost tributes from districts three, four, seven, eight, and nine cannot maintain or survive with the condition and situation; they cannot help themselves and perish for their weaknesses. In the next scene from The Hunger Games: Catching Fire, the Killability test also showed when Katniss's opposite allies attack and destroy Katniss' grandstand. They were finally killed by Katniss's allies. The opposite allies cannot cooperate and incapable of changing to form a rebellion and escape from the bloody game; thus, they deserve to get punishment.

During almost all the scenes in the movies performed death as means of killability test. This killability test also shows how people cannot maintain or survive with the condition and situation; they cannot help themselves and perish for their weaknesses. This is to test that they have already proven that they are incapable of changing (2010, p. 26-27).

In the killability test, death is meaningful in relation to the past by killing or destroying someone who could not be stopped and deserves to get punished. This death is intended for people who refuse to leave their evil ways, as seen from the character of President Snow. He becomes the target of the 
protagonist to kill. The death of this evil character reflects how death can be meaningful by relating the past tragic experience to pursue freedom. Although this seems ironic, hence this definition of death cannot be put aside from the reality in the movies.

The death of President Snow at the end in the scene The Hunger Games: Mockingjay as the killability test is strongly influenced by the character by him who was someone who cannot be stopped for his brutality, cruelty, and malignancy. He caused many people to die in The Hunger Games, killed innocent people in a great number; children and women, young and old, and destroyed the districts into ashes mercilessly. In fact, the killability is not only for President Snow but also for all the people in Capitol who support his ruthlessness are worthy of being killed. Here, death is meaningful in relation to the past is shown by the death of people who could not be stopped, refuse to leave the evil ways, cannot maintain or survived with the condition and situation, and are incapable of changing; thus, they deserve to be punished.

\section{Subletting Death}

Hagin mentioned that mostly Hollywood cinemas are based on causality through the actions of individuals; losing a character midstory can put a terrible burden on the narrative and incur difficulties, challenges, and strains to the individual-driven storyline. Moreover, in fact, the living character is also affected by death $(2010$, p. 45). The death of Rue from district eleven in the scene of The Hunger Games brings impact to Tresh as her partner from the same district kills Cato's girl for murdering Rue. Later, the death of Tresh and Rue brings impact to the living characters such as Katniss and all the people in district eleven to form disobedience to the Capitol. For Katniss herself, she was motivated to take revenge on the tributes that killed Rue sadistically. On the other hand, the narration of Katniss' father's death also keeps being mentioned from the first film until the last one. The death of Katniss's father brings an impact to her to stay alive, which later makes great differences and chances for many people in the future.

Death can be the issue or reason for someone to stay alive and discuss the bonds that entangle living characters in the death of others and thus enable death to be meaningful in relation to the future as what has been done by the major character in the film, Katniss Everdeen. She is a very strong girl who fights for her family's living, replacing his father's duty that died because of a mining explosion. She volunteers herself to replace her younger sister Prim to involve in the game with Peeta Mellark and enter Capitol to meet the other tributes and gain sponsors in the debut. The sublating death here means that the death of Katniss's father leaves something behind in a way that allows Katniss to continue her progress to the next stages.

The scene in The Hunger Games: Catching Fire where Katniss shows the video which is aimed to be aired lively to the remaining districts about the dead people from all over districts and also from a hospital that the Capitol burned into ashes trigger all people in the entire districts to take revenge to the Capitol. The death of numerous people in the past motivates the survival districts to form rebellion and revolution to form new hope; a new Panem where people can live peacefully. Moreover, the death from the people in the past from all districts was still be projecting 
until the end of the film as the reminder of President Snow's evil reign, from the Capitol, and from the inhuman Panem. This shows a collective memory which refers to the joint memories held by a community about the past (Hunt, 2010: 97). The relationship between memory with history can bring all the districts to remember what the capitol has done to them. The death of the tributes and all the victims can affect the uprising in the future to get freedom.

\section{Obstacles and Goals}

Death is meaningful in relation to the future is shown in The Hunger Games when the girl from district one and boy from district ten died for Trackjackers' poison. It happened when Katniss was trapped on top of the tree while Cato's allies were waiting for her down the tree to kill her. Katniss could not escape from them until Rue from district eleven suggested she cut down the Trackjackers on the branch of a tree and attacked Cato's allies down the tree. The Trackjackers are lethal animal which are genetically engineered wasps, whose venom cause severe pain, powerful hallucination and in extreme cause death. Two of them remove the poison. The death of the two tributes remove Katniss's obstacle; therefore, she could continue her struggle to win the game, or to be precise, stay alive. Death in here is centered on causality, consequence, psychological motivations, and the drive toward overcoming obstacles and achieving goals; Hagin gives an explanation on how death can be meaningfully in functions in relation to events that come before or after it in a personal linear causal storyline.

In the scene of The Hunger Games: Catching Fire, death can be meaningful in relation to the future in giving advantages to the living people, is proven by the death of Mags for killing herself by confronting the poison fog to remove the obstacle for another living tributes such as Katniss, Peeta, and Finnick. Mags did not want to be a burden to Finnick and friends because she knew that she was too old to stay alive in the game, and killing herself will make Finnick and friends staying alive. Furthermore, the death of Morphlings' bother removed the obstacle for Peeta to stay alive from the deadly monkeys.

In setting a goal, death can be meaningful in relation to the future is shown in the scene of The Hunger Games: Mockingjay I, where the death from the entire people in district twelve make a demand on the living, create a new goal for Katniss. Here, Katniss' anger in seeing her people in her hometown died into ashes from the Capitol bombing triggered her to take revenge to the Capitol by agreeing to be Mockingjay as a symbol of rebellion and revolution to destroy the Capitol. This can be seen from Katniss' narration:

"My name is Katniss Everdeen. I am seventeen years old. My home is District 12. There is no District 12. I am the Mockingjay. I brought down the Capitol. President Snow hates me. He killed my sister. Now I will kill him. And then The Hunger Games will be over....".

Moreover, the death of the refugees in the hospital who were also burned into ashes by the Capitol led her and also all the survival districts to really rethink the existence of President Snow, who has inhuman morality. Katniss and all the survival districts had a new goal which was to destroy President Snow and his Capitol. This is strengthened by Katniss's narration, "Fire is catching! And if we burn, you burn with us!" Furthermore, by the end of the struggle in The Hunger Games: 
Mockingjay I, the death of the people in the past created a new goal to set a new Panem which can be their new place of hope for a better life in the future. Death as Obstacles and Goals can be meaningful in relation to the future is by giving advantages to the living people by killing the Capitol army, which creates a goal for their freedom. The death of someone removes obstacles to the living person, and the death itself also can help the living person setting or reaching his or her goals (2010, p. 46-47).

\section{Desiring Death}

Death can be a desire to reach a goal, and death itself can actually be the goal. The desiring death is when the goal or desire of the living are contradictory or not fully known to them, or in other words, death can be desirable by creating a lack that needs to be filled (2010, p. 53-54). This meaning of death can be found in the scene The Hunger Games: Catching Fire when Finnick was already desperate to win the game from many obstacles in the arena such as flash floods, dehydration, poison fog, infection, dangerous animals, and all terrible situations in the arena. Finnick was also desperate to face other tribute's threats for hunting him continuously. But his desperation from all the obstacles led him to always come back to win the game because he wanted to find his girlfriend. He set all the deaths in the area as a goal to be a winner. This meaning of death as a desire to stay alive is strongly influenced by the lack of his life without his loved one.

In another scene, the death of the tributes becomes the goal for Katniss to continue the uprising towards the Capitol and end the game. The desire and goal from her later bring all the death scenes into freedom eventually.
This desire for death is also can be created intentionally by the superpower or the Capitol. They deliberately created the game to create a gap within everyone's heart in the districts to be submissive to them and follow their order. The gap itself was created to form rule and act as the law that needs to be obeyed. Once it is broken, the deaths from the districts cannot be avoided as Hagin stated that in the films, the end must reply to the beginning; the last scene frequently recalls the first and constitutes its resolution (2010, p. 57).

\section{Retaining the Death}

In Retaining the Dead, Hagin mentions that death needs to bring interest not only for the dead but also for the living in order to be meaningful in relation to the future in a personal causal storyline. A cult or a collectivity is needed for the dead to be retained, to escape their death (2010, p. 66). Here the scene in The Hunger Games, Katniss held a simple burial for Rue's dead body because she was still in the game and cannot arrange a deserve burial. Katniss could not bring Rue's dead body to the district but leaving in the arena by putting flowers around Rue's body, and when she left, she pointed tree fingers as a note, the symbol of rebellion, to the aired camera to show how she hated the game and cursed it to everyone outside the arena. The portrait of honoring the dead body in a simple yet beautiful burial shows the bonds that entangle living characters in the death of others. This shows that the social group related to the dead is necessary for death in relation to the future.

A cult or a collectivity is needed for the dead to be retained, to escape their death. Hagin showed this death definition by giving an example in the film The Grapes of Wrath 
where one member of the family died during the travel; the family seems to be disintegrating and unable to serve its members, as do many other social institutions, the living family still conduct a simple burial for the dead grandfather to honor the dead and leave a note behind (2010, p. 67). This also happened in The Hunger Game when Katniss' conducted a speech during the tour to district eleven to show her compassion to the family of the lost tributes "I didn't know Thresh. I only spoke to him once. He could have killed me, but instead, he showed me mercy. That's a debt I'll never be able to repay. I did know Rue. She wasn't just my ally, she was my friend. I see her in the flowers that grow in the meadow by my house. I hear her in a Mockingjay song. I see her in my sister, Prim. She was too young, too gentle. And I couldn't save her. I'm sorry". This beautiful narration shows how she was sorry for cannot save Rue's life and could only arrange a simple burial for her. The simple cult can be memorable to Katniss and to Rue's family to honor Rue's struggle in the Hunger Game. This death gives meaning to all the living that deaths can bring hope and a better future for not only all the living but also for the dead soldiers who sacrificed their lives in the arena. As the retaining the death, the death burial by the tribute Rue gives meaning to the death; that there is a cult to retain your memory and a collective who will make the death be remembered as beautiful death.

\section{CONCLUSION}

Based on the findings and discussions in the analysis above, some conclusions can be drawn related to the research questions and objectives of the research, as stated in the introduction part. The researcher found the meaning of death in The Hunger Games trilogy films using Hagin's framework of Death in Classical Hollywood Cinema. Started with Death in Line, how death can be meaningful in philosophy by making a connection between morality and time can be seen in the scene of The Hunger Games when the death from people in district twelve in the past encourages Katniss to struggle to win the game to protect her district from destruction. The morality value lies in how the death from the past can save the death of the living people in the future. For the Politic of Death, we can see how the death of people in the past can trigger the survival people to start a rebellion against the Capitol reign to build a new Capitol.

As the Access, Authority, and Test, death is meaningful in the shifting from ignorance to knowledge and also as a test can be seen in how Katniss and Peeta really understand how to survive in the game using their knowledge that they got from seeing the death of other tributes for eating poison berries and also setting a fire in the arena. The killability test can be seen in the general goal for Katniss. Other people in districts to kill President Snow and all people who support his reign because they could not be stopped, refuse to leave the evil ways, cannot maintain or survived with the condition and situation, and are incapable of changing; therefore, they deserve to get punished, to be killed.

The subletting death can be seen in the scene in The Hunger Games: Catching Fire, where the death of numerous people in the past motivates the survival districts to form rebellion and revolution to the Capitol. The removing obstacles can be found in the death of Mags to save Finnick and friend in setting their goal to win the game. In the scene of The Hunger Games: Mockingjay I, the death of the 
entire people in district twelve make a demand on the living, create a new goal for Katniss to agree to be Mockingjay as a symbol of rebellion. The next meaning of death, the Desiring Death, can be found in The Hunger Games: Catching Fire scene when Finnick wants to die as the goal of the game. The death itself is the goal of Finnick in the game. In Retaining the Death, Katniss held a simple burial for Rue's dead body because she was still in the game and cannot arrange a deserve burial. Katniss could not bring Rue's dead body to the district but leaving in the arena by putting flowers around Rue's body; death can be meaningful in relation to the future by retaining the death of Rue's body. Overall, the discussion above shows the meaning of death in The Hunger Games trilogy films using Hagin's framework of Death in Classical Hollywood Cinema.

\section{REFERENCES}

Adkins, B. (2007). Death and desire in Hegel, Hiedegger and Deleuze. Edinburgh University Press.

Aries, P. (1976). Western attitudes toward death from the middle ages to the present. The Johns Hopkins University Press.

Armstrong, R. (2011). Review: Boaz Hagin (2010) Death in classical. filmphilosophy, ISSN: 1466-4615, 126.

Bauman, Zygmunt. (1992). Intimations of postmodernity. Routledge.

Boxofficemojo. (2015, April 15). Weekend report: Four-in-a-row for 'The Hunger Games'".

Creswell, J. W. (2009). Research design: Qualitative, quantitative, and mixed method approaches (third edition). Sage Publications, Inc.

C.Hunt, Nigel. (2010). Memory, war, and trauma. Cambridge University Press.
Davis, J Doughlas. (2005). A brief history of death. Blackwell Publishing.

Hagin, B. (2010). Death in classical Hollywood cinema. Palgrave Macmillan.

Hakola and Sari Kivistö. (2014). Death in literature. Cambridge Scholar Publishing.

Krippendorf, K. (1981). Content analysis: An introduction to its methodology. Sage Publication.

Kubler-Rose, Elizabeth. (2009). On death and dying. Routledge.

Sterritt, D. (2011). [Review of the book $A$ Grammar of murder: Violent scenes and film form, by Karla Oeler and Death in classical Hollywood cinema, by Boaz Hagin. Film Quarterly, 65(2), 78-80.

Straaten, T. V. (2015, June 19). The Hunger Games.

Kastenbaum, R. (2003). Definitions of death. In R. Kastenbaum (Ed.), Macmillan Encyclopedia of death and dying. Macmillan Reference USA.

Whited, L. A. (2012). The Hunger Games Review. Journal of Appalachian Studies, 18(1/2), 326-331. 